\title{
Organoleptic, Physical and Microbiological \\ Characteristics of Eggs Consumed in Dakar (Senegal)
}

\author{
Abdelsalam Adoum Doutoum (Corresponding author) \\ Higher National Institute of Sciences and Technology of Abeche \\ P.O. Box 130 Abeche, Chad \\ Inter-State School of Veterinary Sciences and Medicine (EISMV)-Hygiene and \\ Foodstuffs Industry of Animal Origin (HIDAOA), Dakar, Senegal \\ Tel: (00235) 99198019/63738173 E-mail: doutoum3000@yahoo.fr
}

\begin{abstract}
Abdelsalam Tidjani
Faculty of Human Health Sciences, University of N'Djamena

P.O. Box 1117, N'Djamena, Chad

Tel: (00235) 95742125 / 66352119 E-mail: abdelti@yahoo.fr

Djamalladine Mahamat Doungous

Higher National Institute of Sciences and Technology of Abeche

P.O. Box 130 Abeche, Chad

Tel: (00235) 63474969 / 90042065 E-mail: djadas2007@yahoo.fr
\end{abstract}

Hamadou Abba

Faculty of Health Sciences of Adam Barka University of Abeche (Chad)

E-mail: hamadouabba@gmail.com

Alioune Ndiaye

Inter-State School of Veterinary Sciences and Medicine (EISMV)-Hygiene and Foodstuffs Industry of Animal Origin (HIDAOA), Dakar, Senegal 


\section{Coumba Faye}

Inter-State School of Veterinary Sciences and Medicine (EISMV)-Hygiene and Foodstuffs Industry of Animal Origin (HIDAOA), Dakar, Senegal

\section{Roumane Moukhtar}

Higher National Institute of Sciences and Technology of Abeche

$$
\text { P.O. Box } 130 \text { Abeche, Chad }
$$

Tel: (00235) 99472656_E-mail: roumane_moukhtar@yahoo.fr

\section{Marius K. Somda}

Center for Research in Biological, Food and Nutritional Sciences (CRSBAN) Department of Biochemistry-Microbiology (DBM), University Ouaga 1 Pr Joseph KI-ZERBO, 03 P.O. Box 7021, Ouagadougou 03, Burkina Faso

\section{Malang Seydi}

Inter-State School of Veterinary Sciences and Medicine (EISMV)-Hygiene and Foodstuffs Industry of Animal Origin (HIDAOA), Dakar, Senegal

E-mail: mgseydi@yahoo.fr

Bhen Sikina Toguebaye

Department of Animal Biology; Cheikh Anta Diop University of Dakar (Senegal) E-mail: toguebaye@ucad.sn

Alfred S. Traore

Center for Research in Biological, Food and Nutritional Sciences (CRSBAN) Department of Biochemistry-Microbiology (DBM), University Ouaga 1 Pr Joseph KI-ZERBO, 03 P.O. Box 7021, Ouagadougou 03, Burkina Faso

Received: July 14, 2018 Accepted: December 4, 2018 Published: December 9, 2018 doi:10.5296/jfs.v7i1.14023ＵRL: https://doi.org/10.5296/jfs.v7i1.14023 


\title{
MInstitute"mk
}

\begin{abstract}
The evaluation of the commercial quality and freshness of consumer eggs in Dakar, Senegal, involved 1,000 egg samples. The values of the physical parameters showed that the eggs had an average weight of $60.3 \mathrm{~g}$ and the average age of 7.6 days. The majority of eggs had an oval shape (98.1\%), $76.8 \%$ of eggs are clean against $23.2 \%$ dirty and $93.4 \%$ of the shells are intact against $6.6 \%$ rugged. On the other hand, $18.3 \%$ of the eggs have a spread albumen, $7.2 \%$ of the whites have foreign bodies, $5 \%$ have stains and no color and odor anomalies with a $\mathrm{pH}$ ranging from 8 to $9,5.21 .4 \%$ of egg yolks are flattened, $86.6 \%$ of normal color, $10.4 \%$ have stains, no embryo development and no odor anomaly with a $\mathrm{pH}$ ranging from 5.7 to 6.5 .

100 eggs were microbiologically tested. The results showed that this food is contaminated internally by Salmonella (1\%), E.coli (1\%), Proteus (1\%), Listeria (2\%) and externally by Salmonella (2\%). E. coli (4\%), Proteus (3\%), Staphyloccocus (5\%).
\end{abstract}

Keywords: Eggs, Freshness, Quality, Microbes, Dakar

\section{Introduction}

In the face of an ever-increasing urban population, animal intensification policies have been implemented to meet animal protein requirements (Dahloum et al., 2015, Hamadou, 2015). the perfect control of poultry farming conditions makes the egg one of the main sources of protein in urban and peri-urban areas (Youssouf et al., 2010). It goes without saying that the egg produced locally and presented to the consumer must justify a quality. The quality of the egg can be defined as the set of characteristics of this egg that depend on all the stages of the poultry industry and that condition its acceptance by the consumer (Missohou et al., 1998). It is a concept, however difficult to specify because the quality criteria are variable (organoleptic, physical, chemical, hygienic, etc...) and in Senegal there is no recent data on the production and sale of eggs for consumption (Ndiaye et al., 2007). But because the egg is a paucimicrobial commodity, it would be more interesting to emphasize the organoleptic and physical criteria in order to update the results concerning the quality of the egg.

Thus we chose to undertake a study on the following subject: "Organoleptic, physical and microbiological characteristics of the eggs consumed in Dakar (Senegal)".

\section{Materials and Methods}

\subsection{Presentation of the Study Area}

The study was conducted over a period of 4 months from 05 January to 08 May 2013 in the city of Dakar. The climate is tropical with two contrasting seasons: a long dry season from November to May and a rainy season from June to October. The average monthly temperatures vary between 16 and $25^{\circ} \mathrm{C}$.

\subsection{Sampling}

A total of 1000 Gallus gallus hens' eggs (from local and breed hens) were collected (by purchase) from the Dakar agglomeration at the rate of 11 trays of 30 units in three different farms and 23 trays of 30 units in the market, 10 among fixed salaries, 3 among street vendors, 7 in shops and 3 in supermarkets.

The sample was made of colored eggs (red eggs). Apart from this criterion, the color of the shell, the trays presented for sale were chosen at random. The samples so chosen were sent to 


\section{MInstitute Macrothink $_{\text {Int }}$}

the laboratory in cardboard trays for analysis. Upon arrival at the laboratory, each tray is registered for a commercial card and the eggs are numbered and studied immediately.

\subsection{Characterization of the Physical and Organoleptic Parameters}

The shape, the color, the grain, the integrity and the cleanliness were appreciated by simple observation of the eggs of each lot. The length and width (large diameter) of the eggs were measured using a flat ruler graduated in millimeters and a graph paper; while the weight of the whole egg was measured using a 0.01 gram SARTORIUS scale.

The densimetry was measured using two plastic beakers containing one of the ordinary water, the other a saline solution containing $12 \%$ of sodium chloride and a glass plate intended to cover the beaker of water salted between manipulations to limit evaporation.

The mirage test was carried out using a locally made light fixture consisting of a rigid and opaque plastic pipe $25 \mathrm{~cm}$ long and $8 \mathrm{~cm}$ in diameter. One of the ends closes with a metal cover, on which is fixed a socket provided with a small spherical electric bulb of 60 watts, at the free end, a metal slider with a concave support allows to introduce an egg in this room up to a distance of $10 \mathrm{~cm}$ from the bulb. It was carried out for three successive positions of the egg with its support: vertical egg, large pole at the top, identical position after rotation of $180^{\circ}$ and horizontal egg, big pole towards the observer.

The characters observed at the mirage being: the shell (the transparency and the integrity), the inner tube (the diameter), the albumen (the transparency, the tasks and the foreign bodies), and the vitellus (Transparency, embryo development and tasks). In view of the insufficient performance of the artisan-type mirror, we have, it has not been possible to make precise measurements of the height of the tube. Nor to estimate the shape of its base. These data are usually used for checking the freshness of the eggs. They require the use of a powerful mirror, allowing a clear and precise examination of the inner tube, as well as a great experience of the observer. Our mirror giving a very vague image, sometimes even nil of the inner tube, so we measured the diameter after breaking. Not having a mirror or an observation chamber with an ultraviolet light (light woods), we could not make any observations on the fluorescence of the shell (search for eggs old, washed or stabilized by the cold).

The breaking was carried out with the aid of a knife and a rectangular glass plate $40 \mathrm{~cm}$ long and $30 \mathrm{~cm}$ wide used to receive the egg mediums. After breaking the egg, the media are poured on a glass plate and are examined. With regard to albumen, the following characteristics have been taken into consideration: form, opacity, smell, color, presence of foreign bodies and presence of tasks. As for yolk, the characters form, color, smell, development of the embryo and presence of tasks were observed.

Whereas the vitellinic index was measured using a flat ruler graduated in $\mathrm{mm}$, the zero being located at one of the ends, this rule makes it possible to measure the height of the yolk and a graph paper placed under the glass plate allowing the reading of the diameter of the vitellus. Vitellinic Indice (IV) is represented by the ratio between the height (HV) and the diameter (DV) of the yolk either: IV = HV / DV

The $\mathrm{pH}$ of the albumen was obtained by pressing the end of a tab of the $\mathrm{pH}$ paper into the albumen, about $2 \mathrm{~cm}$ from the yolk. The reading is performed at the end of approximately 30 seconds in comparison with a colorimetric scale. The yolk $\mathrm{pH}$ was obtained by depositing on 


\section{Ml Macrothink}

a strip of colored paper and a few drops of yolk taken through the yolk sac using a needle. The reading is also made under the same conditions as above.

\subsection{Isolation, Preliminary Characterization and Identification of Pathogenic Bacteria}

The search for Salmonella and Proteus is carried out according to the French standard ISO 6579, in 4 stages: pre-enrichment, enrichment, isolation and biochemical identification.

\subsubsection{Pre-enrichment}

Five eggs were broken and placed in a Stomacher bag containing $225 \mathrm{ml}$ of buffered peptone water, and incubated at $37^{\circ} \mathrm{C}$ for $24 \mathrm{~h}$.

\subsubsection{Enrichment}

Enrichment was performed simultaneously on two media. Using Pasteur pipettes, $0.1 \mathrm{ml}$ and $1 \mathrm{ml}$ of pre-enrichment were taken and added to $10 \mathrm{ml}$ of Rappaport Vassilliadis Soy (RVS) and $10 \mathrm{ml}$ of Mueller Kauffman Tetrathionate Novobiocine Broth (MKTTn) respectively. The MKTTn tubes were incubated at $37^{\circ} \mathrm{C}$ for 18 to 24 hours and the RVS tubes at $42{ }^{\circ} \mathrm{C}$ for 18 to 24 hours.

\subsubsection{Isolation and Characterization}

Suspected colonies Salmonella spp. have undergone primary characteristic tests, the catalase test and Gram stain and fresh examination. Characteristic Salmonella isolates stored at $-20{ }^{\circ} \mathrm{C}$ in CCB plus $25 \%$ for Api 20 E. gallery test.

The search for E. coli is carried out according to the French standard ISO 16654. Using Pasteur pipettes $0.1 \mathrm{ml}$ of the sample was spread on the EMB agar and incubated at $42{ }^{\circ} \mathrm{C}$. for 18 to 24 hours. Suspected colonies of E. coli, were tested, catalase, Gram stain and minimal gallery. Salmonella isolates characteristic preserved at $-20{ }^{\circ} \mathrm{C}$ in $\mathrm{BCC}$ plus $25 \%$ for Api gallery test $20 \mathrm{E}$.

The search for Staphylococcus was carried out according to the French standard ISO 6888-1. Using Pasteur pipettes $0.1 \mathrm{ml}$ of the sample was spread on Baird-Parker and incubated at $37{ }^{\circ} \mathrm{C}$ for 18 to 24 hours. Suspected colonies of Staphylococcus were tested for catalase, coagulase, Gram stain. Staphylococcus isolates were stored at $-20{ }^{\circ} \mathrm{C}$ in $25 \% \mathrm{CCB}$.

The research of Listeria was carried out according to the French norm ISO11290-1 / A1. Using Pasteur pipettes, $0.1 \mathrm{ml}$ of the enrichment broth was spread on PALCAM agar. After 24 hours of incubation (on PALCAM agar), Listeria spp. forms olive-green colonies with a black center and is surrounded by black areas. Suspicious colonies were subjected to biochemical identification tests.

\subsection{Statistical Analysis}

The collected data were analyzed by ANOVA using XLSTAT software version 7.5.2. Descriptive statistics (mean, standard deviation) were given for each variable.

\section{Results}

\subsection{Examination Before Breaking}

Visual examination of the shell. The results of the visual examination are shown in Table 1. 
Table 1. Visual inspection of the shell

\begin{tabular}{llll}
\hline Characters & & Number & Percentage (\%) \\
\hline \multirow{4}{*}{ Form } & Ovoid & 981 & 98.1 \\
& Protruding & 6 & 0.6 \\
& Elongated & 13 & 1.3 \\
& Total & $\mathbf{1 0 0 0}$ & $\mathbf{1 0 0}$ \\
\hline \multirow{5}{*}{ Grain } & Smooth & 939 & 93.9 \\
& Rough & 61 & 6.1 \\
\multirow{5}{*}{ Integrity } & Total & $\mathbf{1 0 0 0}$ & $\mathbf{1 0 0}$ \\
& Normal & 934 & 93.4 \\
& Damaged & 55 & 5.5 \\
& Cracked & 11 & 1.1 \\
\multirow{3}{*}{ Cleanliness } & Total & $\mathbf{1 0 0 0}$ & $\mathbf{1 0 0}$ \\
& Clean & 768 & 76.8 \\
& Soiled & 232 & 23.2 \\
\hline
\end{tabular}

Table 1 gives the shape, grain, integrity and cleanliness of the eggs. This analysis shows that $98.1 \%$ of the eggs are ovoid, $1.3 \%$ are elongated and $0.6 \%$ are globular; $93.9 \%$ of the eggs are smooth whereas the rough shells represent $6.1 \% ; 6.6 \%$ of the eggs have an altered shell and $93.4 \%$ have a normal shell and in the end $23.2 \%$ of the eggs studied are contaminated against 76.8 healthy shells.

Table 2. Nature of the stains of the shell

\begin{tabular}{lll}
\hline Nature & Number & Percentage (\%) \\
\hline Dropping & 214 & 92.2 \\
Blood & 12 & 5.2 \\
Sand & 3 & 1.3 \\
Food & 3 & 1.3 \\
Total & $\mathbf{2 3 2}$ & $\mathbf{1 0 0}$ \\
\hline
\end{tabular}

Table 2 shows that the shells soiled by droppings occupy the highest proportion, i.e. $92.2 \%$, the stains or streaks of blood represent $5.2 \%$ of the dirt and the other stains (sand, food, etc.) make $2.6 \%$. 


\section{Macrothink}

Table 3. Diameter ( $\mathrm{mm})$ of the eggs

\begin{tabular}{lll}
\hline Class & Diameter $(\mathbf{m m})$ & Percentage $(\mathbf{\%})$ \\
\hline$[\mathbf{3 8 - 3 9}]$ & 1 & 0.1 \\
{$[\mathbf{4 1 - 4 2}]$} & 4 & 0.4 \\
{$[\mathbf{4 2 - 4 3 ]}$} & 42 & 4.2 \\
{$[\mathbf{4 3 - 4 4 ]}$} & 159 & 15.9 \\
{$[\mathbf{4 4 - 4 5}]$} & 248 & 24.8 \\
{$[\mathbf{4 5 - 4 6 ]}$} & 333 & 33.3 \\
{$[\mathbf{4 6 - 4 7 ]}$} & 138 & 13.8 \\
{$[\mathbf{4 7 - 4 8}]$} & 55 & 5.5 \\
{$[\mathbf{4 8}-\mathbf{4 9}]$} & 16 & 1.6 \\
{$[\mathbf{4 9 - 5 0}]$} & 4 & 0.4 \\
Total & 1000 & 100 \\
\hline
\end{tabular}

As shown in Table 3, the average diameter of eggs is about $44.6 \mathrm{~mm}$; the largest differences recorded are $38 \mathrm{~mm}$ (minimum value) and $50 \mathrm{~mm}$ (maximum value).

Table 4. Distribution of heights ( $\mathrm{mm})$ of eggs

\begin{tabular}{lll}
\hline Class & Height $\mathbf{( m m )}$ & Percentage $(\%)$ \\
\hline$[\mathbf{3 0 - 3 4}]$ & 1 & 0.1 \\
{$[\mathbf{5 0 - 5 4}]$} & 19 & 1.9 \\
{$[\mathbf{5 4 - 5 8}]$} & 373 & 37.3 \\
{$[\mathbf{5 8 - 6 2}]$} & 519 & 51.9 \\
{$[\mathbf{6 2}-\mathbf{6 6}]$} & 84 & 8.4 \\
{$[\mathbf{6 6}-\mathbf{7 0}]$} & 4 & 0.4 \\
Total & 1000 & 100 \\
\hline
\end{tabular}

Table 4 shows that the average egg height is $58.1 \mathrm{~mm}$, the minimum value is $30 \mathrm{~mm}$ and the maximum is $69 \mathrm{~mm}$

The Table 5 shows that the average weight of eggs is about 60.3 grams. The maximum weight is 82 grams and the minimum weight is 38 grams. 


\section{Macrothink}

Table 5. Weight distribution

\begin{tabular}{lll}
\hline Class & Weight $(\mathbf{g})$ & Percentage $(\%)$ \\
\hline$[\mathbf{3 9 - 4 3 ]}$ & 1 & 0.1 \\
{$[\mathbf{4 3 - 4 7 ]}$} & 2 & 0.2 \\
{$[\mathbf{4 7 - 5 1 ]}$} & 15 & 1.5 \\
{$[\mathbf{5 1 - 5 5}]$} & 105 & 10.5 \\
{$[\mathbf{5 5 - 5 9 ]}$} & 260 & 26 \\
{$[\mathbf{5 9 - 6 3}]$} & 309 & 30.9 \\
{$[\mathbf{6 3 - 6 7}]$} & 188 & 18.8 \\
{$[\mathbf{6 7 - 7 1 ]}$} & 81 & 8.1 \\
{$[\mathbf{7 1 - 7 5 ]}$} & 29 & 2.9 \\
{$[\mathbf{7 5 - 7 9 ]}$} & 6 & 0.6 \\
{$[\mathbf{7 9 - 8 3}]$} & 4 & 0.4 \\
Total & 1000 & 100 \\
\hline
\end{tabular}

Immersion in ordinary water: The results obtained after immersion of the egg in ordinary water are: $41.2 \%$ of the eggs adopt a horizontal position at the bottom of the jar, $52.8 \%$ are inclined at $30^{\circ}-45^{\circ}$ at the bottom, $5 \%$ are inclined at $90^{\circ}$ at the bottom and $0.3 \%$ are between two waters and only $0.7 \%$ are on the surface

Immerse in salt water: $51.7 \%$ is fixed to the bottom of the jar in an upright position, the large end pointing upwards, $25.1 \%$ of the eggs float to the surface, $20.6 \%$ are fixed at the bottom, but in a position inclined at $30^{\circ}-40^{\circ}$ and $2.6 \%$ detach from the bottom of the jar, that is to say are between two waters.

\subsection{Mirage}

The mirage observations reveal that $98 \%$ of the shells are transparent, $0.4 \%$ of the eggs have opaque albumen, $1.8 \%$ of the yolks are opaque, $96.3 \%$ of the yolks are in the central position and only $3,7 \%$ are in marginal position. It has not been revealed the presence of an embryo in the yolk.

\subsection{Post-break Examination}

From this table 6 , it appears that $3.5 \%$ of eggs do not have a tube; the average diameter of the inner tube is $16.7 \mathrm{~mm}$ with a maximum of $30 \mathrm{~mm}$ or $35.3 \%$. 


\section{Macrothink}

Table 6. Diameter of the air chamber

\begin{tabular}{lll}
\hline Class & Diameter & Percentage (\%) \\
\hline$[\mathbf{0 - 6}]$ & 35 & 3.5 \\
{$[\mathbf{6 - 9}]$} & 72 & 7.2 \\
{$[\mathbf{9 - 1 2}]$} & 94 & 9.4 \\
{$[\mathbf{1 2 - 1 5}]$} & 101 & 10.1 \\
{$[\mathbf{1 5 - 1 8}]$} & 115 & 11.5 \\
{$[\mathbf{1 8 - 2 1}]$} & 353 & 35.3 \\
{$[\mathbf{2 1 - 2 4 ]}$} & 157 & 15.7 \\
{$[\mathbf{2 4 - 2 7 ]}$} & 47 & 4.7 \\
{$[\mathbf{2 7 - 3 0 ]}$} & 26 & 2.6 \\
Total & 1000 & 100 \\
\hline
\end{tabular}

Table 7. Densimetry

\begin{tabular}{llll}
\hline Solution & Position of egg & Number & Percentage (\%) \\
\hline & Horizontal at the bottom & 412 & 41.2 \\
& Inclined at $30^{\circ}$ & 412 & 41.2 \\
\multirow{3}{*}{ Ordinary water } & Inclined at $45^{\circ}$ & 116 & 11.6 \\
& Inclined at $90^{\circ}$ & 50 & 5 \\
& In the middle of the water & 3 & 0.3 \\
& On the Surface & 7 & 0.7 \\
& Total & $\mathbf{1 0 0 0}$ & $\mathbf{1 0 0}$ \\
\hline & Vertical at the bottom & 517 & 51.7 \\
Salt water 12\% & Inclined from 30 to 40 & 206 & 20.6 \\
& Detached at the bottom & 26 & 2.6 \\
& Fleet on the surface & 251 & 25.1 \\
& Total & $\mathbf{1 0 0 0}$ & $\mathbf{1 0 0}$ \\
\hline
\end{tabular}

Examination after breaking: Examination of egg environments

The results of the examination of the egg media are given in Table 8 . 
Table 8. Examination of the egg media

\begin{tabular}{|c|c|c|c|c|}
\hline \multicolumn{3}{|l|}{ Egg media } & \multirow{2}{*}{$\begin{array}{l}\text { Number } \\
817\end{array}$} & \multirow{2}{*}{$\begin{array}{l}\text { Percentage (\%) } \\
81.7\end{array}$} \\
\hline \multirow{9}{*}{ Albumen } & \multirow{3}{*}{ Form } & Normal & & \\
\hline & & Spread & 183 & 18.3 \\
\hline & & Total & 1000 & 100 \\
\hline & \multirow{3}{*}{ Foreign body } & Absence & 928 & 92.8 \\
\hline & & Presence & 72 & 7.2 \\
\hline & & Total & 1000 & 100 \\
\hline & \multirow{3}{*}{ Task } & Absence & 950 & 95 \\
\hline & & Presence & 50 & 5 \\
\hline & & Total & 1000 & 100 \\
\hline \multirow{10}{*}{ Yolk } & \multirow{3}{*}{ Form } & Normal & 786 & 78.6 \\
\hline & & Flattened & 214 & 21.4 \\
\hline & & Total & 1000 & 100 \\
\hline & \multirow{3}{*}{ Task } & Absence & 896 & 89.6 \\
\hline & & Presence & 104 & 10.4 \\
\hline & & Total & 1000 & 100 \\
\hline & \multirow{4}{*}{ Color } & Normal & 866 & 86.6 \\
\hline & & Dark & 35 & 3.5 \\
\hline & & Clear & 99 & 9.9 \\
\hline & & Total & 1000 & 100 \\
\hline
\end{tabular}

Albumen: $18.3 \%$ of the eggs have spread albumen; against $81.7 \%$ have a normal form. $7.2 \%$ of the whites have foreign bodies compared to $92.8 \%$ with no foreign bodies, $5 \%$ have stains and no color and odor anomalies.

yolk: $21.4 \%$ of yolk are flattened, $86.6 \%$ of colors are normal, $9.9 \%$ of yellows are clear and only $3.5 \%$ are dark, $10.4 \%$ of yolk have tusks, no development embryo and no odor anomaly.

Table 9. $\mathrm{pH}$ Measurement of the Albumen

\begin{tabular}{lll}
\hline Class & pH & Percentage (\%) \\
\hline$[\mathbf{8 . 0 - 8 . 2}]$ & 3 & 0.3 \\
{$[\mathbf{8 . 2 - 8 . 4}]$} & 7 & 0.7 \\
{$[\mathbf{8 . 4 - 8 . 6 ]}$} & 27 & 2.7 \\
{$[\mathbf{8 . 6 - 8 . 8}]$} & 56 & 5.6 \\
{$[\mathbf{8 . 8}-9.0]$} & 148 & 14.8 \\
{$[\mathbf{9 . 0}-9.2]$} & 312 & 31.2 \\
{$[\mathbf{9 . 2}-9.4]$} & 268 & 26.8 \\
{$[\mathbf{9 . 4 - 9 . 6}]$} & 150 & 15 \\
{$[\mathbf{9 . 6}-9.8]$} & 29 & 2.9 \\
Total & 1000 & 100 \\
\hline
\end{tabular}




\section{Macrothink}

Journal of Food Studies ISSN 2166-1073 2018, Vol. 7, No. 1

Table 9 shows that the eggs analyzed have basic albumen. The average $\mathrm{pH}$ value of the albumen is 9.1; the maximum value is 9.8 and the minimum is 8 .

Table 10. Yolk pH measurement

\begin{tabular}{|c|c|c|}
\hline Class & Yolk pH & Percentage (\%) \\
\hline$[5.7-5.8]$ & 4 & 0.4 \\
\hline [5.8-5.9] & 13 & 1.3 \\
\hline [5.9-6.0] & 59 & 5.9 \\
\hline [6.0-6.1] & 82 & 8.2 \\
\hline [6.1-6.2] & 125 & 12.5 \\
\hline [6.2-6.3] & 234 & 23.4 \\
\hline [6.3-6.4] & 152 & 15.2 \\
\hline [6.4-6.5] & 109 & 10.9 \\
\hline [6.5-6.6] & 100 & 10 \\
\hline [6.6-6.7] & 32 & 3.2 \\
\hline [6.7-6.8] & 38 & 3.8 \\
\hline [6.8-6.9] & 22 & 2.2 \\
\hline [6.9-7.0] & 9 & 0.9 \\
\hline [7.0-7.1] & 17 & 1.7 \\
\hline [7.1-7.2] & 4 & 0.4 \\
\hline Total & 1000 & 100 \\
\hline
\end{tabular}

Table 10 shows that $97.9 \%$ of eggs have an acid yolk compared to $2.1 \%$ have a neutral yolk. The maximum value of the yolk's $\mathrm{pH}$ is 7.2 ; the average $\mathrm{pH}$ is 6.28 and the minimum is 5.7.

Table 11. Yolk index measurement (Y.I)

\begin{tabular}{lll}
\hline Class & Y.I & Percentage (\%) \\
\hline$[\mathbf{0 . 2 1 - 0 . 2 5 ]}$ & 9 & 0.9 \\
{$[\mathbf{0 . 2 5 - 0 . 2 9 ]}$} & 10 & 1 \\
{$[\mathbf{0 . 2 9 - 0 . 3 3 ]}$} & 14 & 1.4 \\
{$[\mathbf{0 . 3 3 - 0 . 3 7 ]}$} & 41 & 4.1 \\
{$[\mathbf{0 . 3 7 - 0 . 4 1 ]}$} & 115 & 11.5 \\
{$[\mathbf{0 . 4 1 - 0 . 4 5}]$} & 238 & 23.8 \\
{$[\mathbf{0 . 4 5 - 0 . 4 9 ]}$} & 199 & 19.9 \\
{$[\mathbf{0 . 4 9 - 0 . 5 3 ]}$} & 157 & 15.7 \\
{$[\mathbf{0 . 5 3 - 0 . 5 7 ]}$} & 156 & 15.6 \\
{$[\mathbf{0 . 5 7 - 0 . 6 1 ]}$} & 57 & 5.7 \\
{$[\mathbf{0 . 6 1 - 0 . 6 5 ]}$} & 3 & 0.3 \\
{$[\mathbf{0 . 6 5 - 0 . 6 9 ]}$} & 1 & 0.1 \\
Total & 1000 & 100 \\
\hline
\end{tabular}




\section{MInstitute Macrothink $_{\text {Int }}$}

Table 11 shows us that the maximum value of the yolk index is 0.67 ; the average value is 0.46 and the minimum value is 0.21 .

Table 12. Prevalence of pathogenic bacteria in and on the chicken egg

\begin{tabular}{lllll}
\hline Bacteria & Egg inside & Percentage (\%) & Egg Outside & Percentage (\%) \\
\hline Salmonella & $1(\mathrm{n}=100)$ & 1 & $2(\mathrm{n}=100)$ & 2 \\
E.coli & $1(\mathrm{n}=100)$ & 1 & $4(\mathrm{n}=100)$ & 4 \\
Proteus & $1(\mathrm{n}=100)$ & 1 & $3(\mathrm{n}=100)$ & 3 \\
Staphylococcus & $0(\mathrm{n}=100)$ & 0 & $5(\mathrm{n}=100)$ & 5 \\
Listeria & $2(\mathrm{n}=100)$ & 2 & $0(\mathrm{n}=100)$ & 0 \\
\hline
\end{tabular}

\section{Discussion}

\subsection{Examination Before Breaking: Visual Inspection of the Shell}

The visual examination allows appreciating the quality of the egg through the information it gives on the shape of the egg, the aspect, the integrity and the cleanliness of the shell.

\subsection{Form}

The shape of the egg is an important parameter for its handling and packaging and even for consumer appreciation. The result of our study shows that $98.1 \%$ of the eggs encountered in the Dakar market have a normal shape, that is to say ovoid. These results are comparable to those of Samandoulougou (2016): $83 \%$ and 92\%. Only 1.9\% of eggs are unconventional (either elongated or globose). This percentage of unconventional form is lower than that found by Angrand (1986): 25.39\% and that of Protais (1988) in PLOUFRAGRAN: 23.4\%. This difference is mainly due to the age dissimilarity of hens because the only factor that affects the shape of the egg is the age of the hen. The elongated form is found in older hens and the rounded shape is usually observed at the beginning of lying.

\subsection{Grain}

The percentage of egg having a rough shell is $6.1 \%$, this result is slightly lower than that of Angrand (1986): $7.55 \%$. The presence of asperities in the shell is most often found in animals cured of respiratory diseases and salpingitis Nickel et al. (1977). These asperities are due to the deposit on the shell formation, mineral salts then covered with limestone and their impact on the strength of the shell is negligible.

\subsection{Integrity}

The integrity of the shell is one of the most important factors that facilitate the conservation of the egg while maintaining intact its internal environment. The percentage of cracked eggs in Dakar is 5.5\%, this is higher than that noted by Angrand (1986) 2.65\%, however it is lower than the result mentioned in France by Protais et al. (8) 6, 3\%. On the other hand, the 1.1\% of the broken eggs remaining superior to the results of Angrand (986) $0.64 \%$ and the result met with PLOUFRAGRAN where the percentage of broken eggs are zero. In a global way the rate of broken shells (cracked and broken) in the Dakar market represents 6.6\%. This is below the rate found in developed poultry countries where 7 to $8 \%$ of shelled eggs are broken (12). These differences can be explained by the intensity of the aggression imposed by the 
equipment during the collection, transport, storage and storage of eggs.

\subsection{Cleanliness}

The test results show that $23.2 \%$ of the eggs are dirty. Compared to the results of Protais (1988) in PLOUFRAGRAN: $2.22 \%$, these are clearly superior. In addition, this percentage is lower than that of Angrand (1986): 30.64\%. This very considerable difference between the results of Dakar and PLOUFRAGRAN reveals insufficient hygiene at the level of the premises and at the level of the laying material (nest boxes). Some defilement is independent of the sanitary condition of the premises and livestock equipment, as is the case with blood traps that often dirty the shells. These have an origin related to the individual, because some hens are often victims of a weakening of the uterine lining at the time of the expulsion of the egg, thus causing these streaks of blood Getty et al. (1975), this blood can also come from a breakdown of hemoglobin by lymphocytes, this is a racial character Thieuling et al. (1976).

\subsection{Measurement of Whole Egg}

Measurement results show that the average diameter (or width) of Dakar eggs is $44.5 \mathrm{~mm}$ and the average height (or length) is $58 \mathrm{~mm}$. The length is comparable to the results of Angrand (1986): $57.7 \mathrm{~mm}$ and Protais (1988) $57.73 \mathrm{~mm}$. Our results are superior to those obtained by Samandoulougou (2016): $\mathrm{L}=48.58 \mathrm{~mm}$ and $1=36.19 \mathrm{~mm}$; Fayeye et al. (2005): $\mathrm{L}=35.24$ and $1=23.59 \mathrm{~mm}$; Keambou et al. (2009): $\mathrm{L}=54.26 \mathrm{~mm}$ and $\mathrm{l}=39.43 \mathrm{~mm}$.

On the other hand, the diameter is greater than that of Angrand (1988) and Protais (1988). This difference noted in terms of the diameter of the eggs is related on the one hand to the animal (age of introduction, the time of spawning its...) and secondly to the diet. According to Obike et al (2012), the length (L) and the large diameter (1) of eggs are proportional to the weight of the animal.

\subsection{Weighing}

The results of the analyzes show that the average weight of eggs encountered in the Dakar market is about $60.2 \mathrm{~g}$. This value is greater than that noted by Angrand (1986): $58.11 \mathrm{~g}$; Samandoulougou et al (2016): 33.86g; Mourad et al. (1997); Missohou et al. (1998). However, it is lower than the result of Protais (1988) $61.9 \mathrm{~g}$.

The variation in weight recorded may be related to the rearing conditions of pullets Protais et al. (1984) on the one hand and on the other hand it may be related to the diet, the breed and the age of the chicken (the older hens give large eggs), genetic divergence (Egahi et al., 2013), climate and vegetation. Thus, according to the genetic variability, the average weight of eggs of local hens is in the weight range of 27 to $54.7 \mathrm{~g}$ (Alkan et al., 2013).

\subsection{Mirage}

Mirage consists of examining the egg by placing it in a dark place between a sufficiently bright light source and the eye of the observer Lederer (1978). This process will make it possible to observe the location and size of the air chamber, the appearance of the yolk, the albumen and the presence of large inclusions. The measurement of the inner tube allows to appreciate the freshness of the egg kept at room temperature because the dimensions of the air chamber to increase as a function of the storage time. The size of this translates into the loss of water and gas under the influence of humidity and ambient temperature during storage. It is therefore possible to find inner tubes that are poorly developed in aged eggs kept under 


\section{MInstitute Macrothink $_{\text {Int }}$}

high humidity. Sauveur (1979). This explains that the inner tube does not allow to fix precisely the age of the egg, but it allows a classification according to a physical quality. We found that in Dakar the average diameter of the tubes is $16.7 \mathrm{~mm}$. The results of analyzes of eggs of the day give a diameter of not more than $13 \mathrm{~mm}$, this diameter can be even zero. These results are comparable to those of Angrand (1986) in which the diameter is $12 \mathrm{~mm}$, Laurent (1974) and Lecoq (1965) who report that the diameter of eggs "of the day" hardly exceeds $10 \mathrm{~mm}$.

\subsection{Densimetry}

The determination of the density of the egg remains an indirect method of assessing the quality of the shell. It is widely used because of its ease of use, its speed and its low cost Protais et al (1985). Moreover, it remains an imprecise method of determining the age of the egg since it is influenced by many factors, including the duration of storage of the egg, the thickness and the structure of the shell which vary with many parameters (diet, temperature, age of the chicken etc....). In addition to these factors, handling and storage conditions can also cause more or less significant changes in density. From a practical point of view, the density of a fresh egg laid is very slightly higher than 1. It does not float on pure water. But the older the egg is with storage time, the inner tube gets larger and therefore the density of the egg decreases, at a certain stage it eventually floats on the water. This elementary finding is used to approximate the age of the egg, the date of which is unknown.

\subsection{Post-Breakage Review: Examination of Egg Environments}

Albumen: The observations are oriented on the form of the albumen, on the separation of thick white and liquid white, but also on the tension of the chalazas. These factors are correlated with the evolution of the egg, so we can estimate the age of the egg. At the level of the albumen we also found dark, white and red spots with the appearance of punctuate colonies. The white spots certainly have a chemical origin (agglomerates of phospho-albuminate crystals of lime) and the red spots result from small, haemorrhages occurring just before ovulation and which detach from the yellow to float in the albumen.

Yolk: The shape of the yolk follows changes with the evolution of the egg. Initially the shape is spherical and then with the storage period, the yellow flattens, so we use the yolk index to estimate the age of the egg. We observed inclusions as spots in the yolk. These are three types of tasks: the dark red spots that come from the blood clotting after the rupture of small blood vessels in the ovary, the white spots have a still poorly known origin and the dark yellow spots of oily appearance appear to be the result of phenomena of lysis of the constituents of the yolk, probably in connection with the osmotic exchanges between the albumen and the yolk. The results reveal that $9.9 \%$ of the yellows are clear, these are inferior to the results of Angrand (1986): $22.65 \%$. The dark color of yellow is represented in 3.5\%, this result also is much lower than that of Angrand (1986): $31.45 \%$. This difference is related to the nature and quality of the pigments ingested by the hen, because the pigment content of the diet directly controls the yolk color and the degree of pigmentation depends on the nature of the carotenoids used. In the vitellus, no embryo development has been found, and there is no particular odor. 


\section{Macrothink}

\subsubsection{Measurement of the $\mathrm{pH}$ of Albumen}

According to Sauveur (1979) cited by Protais (1988), the egg undergoes, after spawning, physicochemical changes, in particular a loss of carbon dioxide of the order of a few milligrams, which causes a rise in the $\mathrm{pH}$ of the albumen, the $\mathrm{pH}$ increases from 7.6 to 9.3 approximately in two days of storage then evolves little. For Protais and Coll. (1981), the egg evolves over time by gradually losing carbon dioxide and water vapor, resulting in a change in the $\mathrm{pH}$ of white and yellow, the average value after 14 or 18 storage days at $18{ }^{\circ} \mathrm{C}$ is 9.55 and 9.6 at $38{ }^{\circ} \mathrm{C}$ against 8.39 for fresh eggs. Our results show that the albumen $\mathrm{pH}$ of eggs sold in Dakar and stored at room temperature varies from 8 to 9.5. So we can estimate that the analyzed eggs do not exceed 14 to 18 days of age. Our results corroborate those obtained by Samandoulougou et al (2016): $\mathrm{pH}$ ranging from 8 to 9; Dahloum et al (2015). According to Mertens et al (2010), the $\mathrm{pH}$ of albumen is a better indicator of egg freshness.

\subsubsection{Measurement of Vitellus $\mathrm{pH}$}

The $\mathrm{pH}$ of the yolk varies slightly from that of the albumen, it increases steadily from 5.9 to 6.4 between the 14th and the 25th day and then stabilizes. It is therefore of no use in determining the age of the eggs. The $\mathrm{pH}$ of the yolk analyzed varies from 5.7 to 6.5. Our results are almost similar to those of Dahloum et al (2015): $\mathrm{pH}=5$ to 6 .

\subsubsection{Measurement of the Yolk Index}

During storage, the highly permeable vitelline membrane allows the exchange of water and mineral salts, these exchanges cause the flattening of the yolk. The flattening of the yolk can be quantified by the yolk index, which is the ratio of the height of the yolk of the diameter of the yolk. According to Piatier (1976), the value of the vitellinic index for an egg "of the day" is close to 0.5 . Our results are comparable to the same age ( 0.56 on average).

Methods for determining the average age of the eggs: Densimetry

Table 13. Age corresponding to the position of the egg immersed in ordinary or salted water $(12 \%)$

\begin{tabular}{lll}
\hline Solutions & Positions & Age (days) \\
\hline & Horizontal at the bottom & $3-4$ \\
& Inclined at $30^{\circ}$ & 8 \\
Ordinary water & Inclined at $45^{\circ}$ & 15 \\
& Inclined at $90^{\circ}$ & 24 \\
& In the middle of the water & 29 \\
\hline \multirow{3}{*}{ Salt water (12\%) } & Fleet on the surface & $\geq 31$ \\
& Vertical & $0-8$ \\
& Detached & $9-24$ \\
& On the surface & $\geq 25-31$ \\
\hline
\end{tabular}

Referring to the results in this table above, our results by densimetric analysis show that the age of the eggs is 7.8 days for the analysis in ordinary water and 10.3 days when immersed in the water. salt water at $12 \%$. 


\section{MInstitute ${ }^{\text {Mnk }}$}

The diameter of the inner tube: The average diameter of the inner tube of the eggs analyzed is $16.7 \mathrm{~mm}$. Referring to the Angrand (1986) data, the corresponding age is 6 days.

Yolk Index: The average yolk index is 0.4 , the age corresponding to this value is 4 days.

Table 14. Comparison of techniques for determining average age of eggs

\begin{tabular}{ll}
\hline Techniques & Age (days) \\
\hline Densimetry at ordinary water & 7.8 \\
Densimetry at salt water 12\% & 10.3 \\
Diameter of the air chamber & 6 \\
Albumen pH & 4 \\
Vitellus pH & $13-15$ \\
Yolk Index & 4 \\
Mean & 6.6 \\
\hline
\end{tabular}

We can therefore say that the average age of eggs marketed in Dakar is 6.6 days. This result is lower than that of Angrand (1986): 8.8 days. This difference is explained by a faster flow of the product following a higher consumption level. For the determination of the age of the eggs, which correlates with the state of freshness, we retain the following three methods:

-the densimetry in ordinary water, it is an imprecise method since the density of the egg is influenced by many factors (quality of the shell, temperature of storage, etc...), however it represents the advantage of being easy to implement. This is the method most used by the housewives and the inspector in the field;

the measurement of the diameter of the air chamber: it is relatively precise and easy to implement if one has the material;

the measurement of the yolk index: it is also relatively precise, but it requires the breaking of the egg.

Finally, we did not find on the market either yellowness and albumen color abnormalities, odor anomalies (food, contamination) or rotten eggs.

\section{Conclusion}

In our countries, poultry farming is undergoing significant development, the increase in the number of farmers and the improvement in productivity have made the egg the most accessible source of animal protein for consumers. The large quantities of egg production on the market, the various marketing channels that they follow lead to a failure to respect the basic rules of quality and hygiene. Eggs undergo many manipulations that greatly influence the nature and importance of the quality of the egg. As a result, the marketing of eggs for consumption requires special control in order to maintain the initial quality of the egg. This is why we have chosen to study the commercial quality of eggs for consumption in the Dakar region. The objective of this work is to give on the one hand the criteria of commercial quality of the eggs and on the other hand to determine by techniques of appreciation of the freshness, the approximate age of the egg. To do this we worked on eggs from all stages of the marketing circuit. A total of 1000 egg samples were processed in the food hygiene 


\section{Macrothink}

laboratory of E.I.S.M.V. of Dakar. The results obtained are: the average weight of the eggs is about $60.3 \mathrm{~g}$ with a minimum of $38 \mathrm{~g}$ and a maximum of $82 \mathrm{~g}, 98.1 \%$ of the eggs have an ovoid shape, and the atypical forms (globose or elongated) are $1.9 \%, 76.8 \%$ of them are clean, the $23.2 \%$ are soiled by droppings, sand, blood, food, $93.4 \%$ of the shells are intact and $6.6 \%$ of casualties are cracked or broken. Egg age determination techniques based on freshness assessment criteria resulted in an average age of 7.6 days. Among these techniques we will remember: densimetry: it is an easy method to implement. Its only disadvantage is its low precision, the measurement of the diameter of the inner tube: it allows to judge approximately the age of the egg, the vitellinic index and the measurement of the $\mathrm{pH}$ of the media (albumen and vitellus) are methods of great precision. They can only be used for surveys because you have to break the egg.

As can be seen, commercial quality management remains insufficient to preserve the initial quality of the egg. It is necessary to take action at different levels.

$>$ At the level of production: a balanced and sufficient diet not to alter the quality of the egg laid (weight, quality of the shells, yellow color), avoid early spawning, respect the density in the hen house, take care of the hygiene of the soil and livestock equipment and handle the eggs carefully during the collection.

$>$ At the marketing level: try to shorten the time to market as much as possible: opt for the use of the clean cells in good condition: respect the storage conditions (environment): ensure the education and maintenance information of the agents involved in the sector and establish a system of quality control and the participation of health services at all stages.

\section{References}

Alkan, S., Karsli, T., Galiç, A., \& Karaba, K. (2013). Determination of phenotypic correlations between internal and external quality traits of guinea fowl eggs. KafkasUniv Vet FakDerg, 19(5), 861-867. https://doi.org/10.9775/kvfd.2013.8988

Angrand, A. (1986). Contribution à l'étude de la qualité commerciale des œufs de consommation de la région de Dakar (Sénégal). Th.: Méd. Vét,: Dakar: 23. Retrieved from http://www.beep.ird.fr/collect/eismv/index/assoc/TD86-23.dir/TD86-23.pdf

Dahloum, L., Halbouche, M., \& Arabi, A. (2015). Evaluation de la qualité des œufs chez deux phénotypes de poules locales: cou nu- frisées et normalement emplumées. Comparaison avec les œufs de souche commerciale. Revue Agriculture, 09, 10-18. Retrieved from http://revue-agro.univ-setif.dz/documents/Numéro- 9/Dalhoum.pdf

EFSA. (2014). The European Union Summary Report on trends and sources of zoonosis, zoonotic agents and food-borne outbreaks in 2012. EFSA Journal, 12(2). Retrieved from https://www.efsa.europa.eu/fr/efsajournal/pub/3547

Egahi, J. O., Dim, N. I., \& Momoh, O. M. (2013). The effect of plumage modifier genes on egg quality indices of the Nigerian local chicken. IOSR Journal of Agriculture and Veterinary Science, 2(2), 04-06. https://doi.org/10.9790/2380-0220406

Fayeye, T. R., Adeshiyan, A. B., \& Olugbami, A. A. (2005). Eggs traits, hatchability and early growth performance of Fulani-ecotype chicken. Livestock Research for Rural Development, 17(8).

Getty, R., \& Grossman's. (1975). The anatomy of the domestic animal. Firth edition, 2, 
1335-1356.

Hamadou, A. (2015). Pratiques d'élevage de poulets et étude de la résistance aux antibiotiques des souches de Salmonella spp. isolées des carcasses au Tchad, Mémoire de Master en biotechnologie Option: Biotechnologie Microbienne et Cellulaire (BMC), Université de Ouagadougou (Burkina Faso).

Keambou, T. C., Boukila, B., Moussounda, G., \& Manjeli, Y. (2009). Comparaison de la qualité des œufs et des performances de croissance des poussins locaux des zones urbaines et rurales de l'Ouest- Cameroun. Int. J. Biol. Chem. Sci., 3(3), 457-465.

Laurent, C. (1974). Conservation des produits d'origine animale en pays chauds. Paris: Presses Universitaire de France, technique vivante: 23-39. Retrieved from http://agris.fao.org/agris-search/search.do?recordID=US201300571370

Lecoq, R. (1965). Manuel des analyses alimentaires et d'expertises usuelles, Ed. Doin: tome II: 1431-1440.

Lederer, J. (1978). Encyclopédie moderne de l'hygiène alimentaire, Ed: 323-339. Retrieved from http://agris.fao.org/agris-search/search.do?recordID=US201300483964

Marie. P. (2015). Biominéralisation de la coquille d'œuf de poule: Caractérisation des protéines de la matrice organique impliquées dans l'initiation de la minéralisation. Thèse pour obtenir le grade de Docteur d'université. Université François Rabelais de Tours -France, 246p. Retrieved from https://www.theses.fr/2015TOUR4007

Missohou, A., Sow, R. S., \& NgweAssoumou, C. (1998). Caractéristiques morphobiométriques de la poule du Sénégal. Animal Genetic Resource Information, 24, 63-69. https://doi.org/10.1017/S1014233900001140

Morita, S. C., Tagai, T., Shiraishi, K. M., \& Iwamura, S. (2013). Differential mode of antimicrobial actions of arginine-rich and lysine-rich histones against Gram-positive, Staphylococcus aureus, 48, 75-82. https://doi.org/10.1016/j.peptides.2013.07.025

Moula, N., Antoine-Moussiaux, N., Decypere, E., Farnir, F., Mertens, K., De Baerdemaeker, J., \& Leroy, P. (2010). Comparative study of egg quality traits in two Belgian local breeds and two commerciallines of chickens. Arch. Geflugekd., 74(3), 164-171.

Ndiaye, S., Bouendeba, B., \& Sanders, J. (2007). La production avicole intensive au Sénégal: Problématique de l'alimentation et place du sorgho?

Nickel, R., Schummer, A. et Seiferle, E. (1977). Anatomy of the domestic birds (pp. 75-84). Berlin. Verlag Paul Parey.

Piatier, C. (1976). Le vétérinaire inspecteur et la nouvelle réglementation des œufs et des ovoproduits. Th:Méd. Vét.: Alfort, 53.

Protais, J. (1988). La qualité de l'œuf de consommation «aviculture française», informations techniques des services vétérinaires, 761-784.

Protais, J., Bougon, M., Launay, M., \& Camard, F. (1985). Evolution du poids et de la densité de l'œuf au cours des trois semaines de stockage. Bul. d'Inf. station Exp. d'aviculture de PLOUFRAGRAN, 25(1), 143-153.

Protais, J., Bougon, M., \& Le Menec. (1984). Influence des conditions d'élevage des poulettes et de l'environnement des pondeuses sur la qualité des œufs. Bul. d'Inf. Station Exp. 


\section{Macrothink}

d'aviculture de PLOUFRAGRAN, 24(3), 153-157.

Protais, J., \& Lahellec, L. M. (1981). Variations de la qualité interne de l'œuf avec la température de stockage. Bul. d'inf. Station Exp. d'aviculture.de PLOUFRAGRAN, 21(1), 39-41.

Rehaut-Godbert, S. V., Labas, E., Helloin, V. Herve-Grepinet, C. Slugochi, M., Berges, M. C. Bourin, A., Brionne, J. C., Poirier, J. Gautron, F. C., \& Nys, Y. (2013). Ovalbumin- related protein XIS a heparin- binding ov- serpin exhibiting Antimicrobiol Activities. Journal of Biological Chemistry, 279(39), 40876-40881.

Samandoulougou, S., Ilboudo, A. J., Sanon, O. G., Bagre, T. S., Tapsoba, F. W., Compaore, H., ... Traore, A. S. (2016). Qualité physico-chimique et nutritionnelle des œufs de poule locale et de race améliorée consommés à Ouagadougou au Burkina Faso.

Sauveur, B. (1979). La qualité des œufs, objet de recherches françaises. Cahier Nutrition Diététique, XIII, 35-45.

Sauveur, B. (1991). Modes d'élevage des poules et qualité de l'œuf de consommation. INRA., Productions Animales, 4(2), 123-130.

Thieuling, G., Basile, D., \& Hautefort, M. (1976). L'œuf et les produits, Paris: Collection Normes et Techniques, 7-51.

Youssouf, M. L. (2010). Revue du secteur avicole du Tchad- Ministère de l'Elevage et des Ressources Animales, Laboratoire de Recherches vétérinaires et Zootechniques de Farcha. Retrieved from http://www.fao.org/docrep/013/ak771f/ak771f00.pdf

Wallman-Labdie, O. R., Lakshmi, N., \& Hinche, M. T. (2008). Antimicrobial properties of avian eggshell-specific-C-type lectin-like proteins. Febs-letters, 582(5), 699-704. https://doi.org/10.1016/j.febslet.2008.01.043

\section{Copyright Disclaimer}

Copyright for this article is retained by the author(s), with first publication rights granted to the journal.

This is an open-access article distributed under the terms and conditions of the Creative Commons Attribution license (http://creativecommons.org/licenses/by/3.0/). 